\title{
Reaksi Pasar Modal Indonesia Atas Pengumuman Kenaikan Tingkat Suku Bunga Acuan Oleh Fed di AS
}

\author{
Kadek Rosita Dewi Indra Pratiwi ${ }^{1}$ \\ I Gede Made Wirakusuma ${ }^{2}$
}

\author{
${ }^{1}$ Fakultas Ekonomi dan Bisnis Universitas Udayana (Unud), Bali, Indonesia \\ email: rositadewi06@gmail.com/Telp:0819367548271 \\ ${ }^{2}$ Fakultas Ekonomi dan Bisnis Universitas Udayana (Unud), Bali, Indonesia
}

\begin{abstract}
ABSTRAK
Tujuan dari penelitian ini adalah untuk menganalisis reaksi pasar modal Indonesia atas kebijakan kenaikan tingkat bunga acuan oleh FED (Fed Fund Rate)yang diukur menggunakan abnormal return dan trading volume activity. Penelitian ini menggunakan pendekatan event study, periode observasi selama lima hari sebelum dan lima hari sesudah peristiwa. Populasi dalam penelitian ini yaitu semua perusahaan yang terdaftar di BEI periode 2018 dan sampel penelitian diambil menggunakan metode purposive sampling. Berdasarkan hasil seleksi sampel sesuai kriteria jadi jumlah sampel yang digunakan adalah 45 perusahaan yang termasuk dalam indeks saham LQ45. Variabel yang digunakan dalam penelitian ini adalah abnormal return dan trading volume activity. Teknik analisis yang digunakan dalam penelitian ini adalah paired sample t-test. Berdasarkan hasil penelitian, reaksi pasar tidak ditunjukkan dengan adanya perbedaan abnormal return sebelum dan sesudah pengumuman kenaikan Fed Fund Rate. Namun, reaksi pasar ditunjukkan dengan adanya trading volume activity sebelum dan sesudah pengumuman kenaikan Fed Fund Rate.

Kata Kunci: Event study, abnormal return, trading volume activity, tingkat suku bunga.
\end{abstract}

\begin{abstract}
The purpose of this study was to analyze the Indonesian capital market's reaction to the policy of increasing the benchmark interest rate by the FED (Fed Fund Rate) which was measured using abnormal returns and trading volume activity. The population in this study is all companies listed on the Stock Exchange in 2018 and the research sample was taken using purposive sampling method. Based on the sample selection results according to the criteria, the number of samples used were 45 companies included in the LQ45 stock index.. The analysis technique used in this study is a paired sample t-test. Based on the results of the study, the market reaction is not indicated by the difference in abnormal returns before and after the announcement of the increase in the Fed Fund Rate. However, market reaction is indicated by trading volume activity before and after the announcement of the Fed Fund Rate increase.

Keywords: Event study, abnormal return, trading volume activity, interest rate.
\end{abstract}

\section{PENDAHULUAN}

Perkembangan aktivitas pasar modal tidak lepas dari peran investor sebagai pemodal dan keterbukaan informasi sebagai pertimbangan pengambilan keputusan investor. Investor dalam pengambilan keputusan berinvestasi saham juga memerlukan pertimbangan, perhitungan dan analisis yang mendalam untuk 
Kadek Rosita Dewi Indra Pratiwi dan I Gede Made Wirakusuma. Reaksi...

menjamin keamanan dana yang diinvestasikan dan pencapaian return yang diharapkan. Alasan pemilihan saham dalam berinvestasi oleh investor adalah untuk memperoleh return yang lebih besar dibandingkan berinvestasi di tempat lainnya seperti meletakkan dana pada sektor perbankan. Informasi baru pada pasar modal akan mempengaruhi harga saham perusahaan dan lebih lanjut akan mempengaruhi pengambilan keputusan oleh investor (Linawati, 2009).

Investor berinvestasi membutuhkan informasi yang relevan untuk mengambil suatu keputusan yang rasional. Informasi yang relevan adalah informasi yang membantu dan memengaruhi investor dalam proses pengambilan keputusan, memiliki nilai umpan balik (feedback value), bisa diprediksi (predictive value), dan harus disajikan tepat waktu sesuai kebutuhan pada saat pengambilan keputusan (timeliness). Investor yang rasional akan melakukan analisis dalam proses pengambilan keputusan investasi.Dalam teori keputusan, konsep keputusan yang rasional berarti bahwa dalam pembuatan keputusan, keputusan yang dipilih adalah keputusan yang akan memberikan kepuasan (utility) yang optimal bagi investor.

Informasi-informasi yang relevan tersebut dapat mempengaruhi keputusan investor dalam bertransaksi di pasar modal yang tercermin dari perubahan harga saham dan tingkat volume perdagangan. Perubahan harga saham dapat terjadi setiap saat, faktor utama yang menyebabkan harga saham berubah adalah adanya berbagai peristiwa baru yang memberikan dampak terhadap perekonomian dan situasi investasi. Peristiwa baru tersebut mengakibatkan perubahan return saham, 
jadi secara tidak langsung peristiwa baru tersebut memberi dampak kepada keputusan investor.

Keputusan investasi yang dilakukan oleh investor merupakan reaksi atas informasi yang mereka terima atau suatu peristiwa yang terjadi, dimana peristiwa tersebut mampu mempengaruhi keputusan mereka dalam berinvestasi (Parmadi, dkk., 2014). Informasi yang dipublikasikan sebagai suatu pengumuman akan memberikan sinyal bagi investor dalam pengambilan keputusan investasi. Para pelaku pasar sebaiknya terlebih dahulu menginterprestasikan dan menganalisis suatu informasi sebagai sinyal baik (good news) atau sinyal buruk (bad news) ketika informasi tersebut diumumkan dan semua pelaku menerima informasi tersebut. Jika pengumuman tersebut mengandung nilai positif, maka diharapkan pasar akan bereaksi pada waktu pengumuman tersebut diterima oleh pasar (Hartono, 2015: 547).

Menurut Alwi (2003:89) Investasi dalam saham dipengaruhi oleh lingkungan internal dan eksternal. Lingkungan internal merupakan faktor yang berhubungan dengan perusahaan itu sendiri, sedangkan lingkungan eksternal merupakan faktor yang berhubungan dengan makro ekonomi. Kondisi ekonomi makro dapat mempengaruhi operasional perusahaan. Hasil keputusan investor dalam menentukan investasi yang menguntungkan salah satunya dipengaruhi oleh kemampuan investor dalam memahami dan meramalkan kondisi ekonomi makro di masa datang. Dalam ekonomi makro terdapat beberapa indikator yang harus dipertimbangkan investor dalam membuat keputusan investasinya (Tandelilin 
Kadek Rosita Dewi Indra Pratiwi dan I Gede Made Wirakusuma. Reaksi...

2010:341). Salah satu faktor ekonomi makro yang mempengaruhi reaksi investor adalah tingkat suku bunga.

Tingkat suku bunga (interest rate) adalah harga dari penggunaan dana investasi (loanable funds).Tingkat suku bunga merupakan salah satu indikator dalam menentukan apakah seseorang akan melakukan investasi atau menabung (Boediono, 2014:76). Tingkat suku bunga juga merupakan salah satu variabel ekonomi yang dipantau oleh pelaku ekonomi karena dinilai memiliki dampak langsung terhadap perekonomian. Hal ini menjadikan tingkat suku bunga sebagai salah satu acuan investor dalam pengambilan keputusan investasi di pasar modal. Adanya informasi baru mengenai kenaikan suku bunga akan mempengaruhi pengambilan keputusan oleh investor. Pada umumnya kenaikan tingkat suku bunga memiliki dampak negatif terhadap setiap emiten, karena akan meningkatkan beban bunga kredit dan menurunkan laba bersih. Penurunan laba bersih akan mengakibatkan laba per saham juga menurun dan berakibat turunnya harga saham di pasar. Sebaliknya, penurunan tingkat suku bunga akan menaikkan harga saham di pasar dan laba bersih per saham, sehingga mendorong harga saham meningkat (Samsul, 2015).

Pada tanggal 22 Maret 2018, Bank sentral Amerika Serikat (The Federal Reserve Bank) dalam pertemuan Federal Open Market Committee (FOMC) memutuskan untuk mengumumkan kenaikan tingkat suku bunga acuan (Fed Fund Rate). The Fed meningkatkan suku bunga acuan jangka pendek sebesar 25 basis poin menjadi kisaran 1,5 persen hingga 1,75 persen dan mencatat total akan ada empat kenaikan suku bunga sepanjang tahun 2018 (www.kompas.com). 
Kebijakan yang dikeluarkan oleh The Fed dapat memberikan dampak positif maupun negatif bagi sebagain negara di seluruh dunia, hal ini dikarenakan Amerika Serikat (AS) merupakan salah satu negara yang memiliki pengaruh besar terhadap kestabilan perekonomian dunia. Pengumuman kenaikan tingkat suku bunga acuan oleh The Fed (Fed Fund Rate)akan memberikan dampak langsung pada pasar Indonesia, terutama pasar uang. Peristiwa ini juga akan berdampak bagi industri pasar modal Indonesia. Peningkatkan Fed Fund Ratedapat meningkatkan jumlah investasi di AS, dimana dapat diprediksi bahwa akan terjadi aliran modal keluar (capital outflow) oleh investor asing di pasar modal Indonesia yang berpengaruh terhadap likuiditas suatu saham. Dampak selanjutnya, terjadi tekanan terhadap mata uang rupiah, sehingga terjadilahpenguatan dolar AS yang signifikan.Pergerakan harga saham mengindikasikan bahwa melemahnya nilai tukar rupiah atas kenaikan Fed Fund Rate menyebabkan investor menjual kepemilikan sahamnya, karena ketika berinvestasi dalam bentuk dolar akan memberikan return yang lebih tinggi bagi investor. Melemahnya nilai tukar rupiah yang signifikan membawa dampak yang beraneka ragam terhadap emiten, dampak yang paling besar akan dirasakan oleh emiten yang mempunyai utang dalam bentuk dolar. Ketika tingkat suku bunga AS naik, beban perusahaan juga akan meningkat, dan akan memberikan dampak negatif bagi emiten, dan berujung penurunan pada IHSG dan return saham. Melemahnya nilai tukar rupiah yang disebabkan atas kenaikan Fed Fund Rate membuat kondisi perekonomian di Indonesia bergejolak dan sangat berpengaruh tehadap kinerja pasar modal. 
Kadek Rosita Dewi Indra Pratiwi dan I Gede Made Wirakusuma. Reaksi...

Secara teori tingkat suku bunga dapat mempengaruhi perkembangan bursa saham khususnya di Bursa Efek Indonesia. Namun, untuk membuktikan secara analisis kuantitatif bahwa pengumuman kenaikan tingkat suku bunga acuan oleh The Fed dapat mempengaruhi pasar modal Indonesia masih perlu pengkajian, karena dilihat dari dampak yang sudah ditimbulkan atas peristiwa ini. Dalam penelitian ini, peneliti ingin mengetahui apakah pasar modal di Indonesia bereaksi terhadap peristiwa ini atau tidak. Salah satu metode yang dapat digunakan yaitu pendekatan studi peristiwa (event study).

Hartono (2015: 623) mendefinisikan, studi peristiwa (event study) merupakan studi yang mempelajari reaksi pasar terhadap suatu peristiwa (event) yang informasinya dipublikasikan sebagai suatu pengumuman. Studi peristiwa (event study) dapat juga digunakan untuk menguji efisiensi pasar bentuk setengah kuat. Jika pengumuman memiliki kandungan informasi, maka diharapkan pasar akan bereaksi pada waktu pengumuman tersebut diterima oleh pasar. Hartono (2015: 548) juga menyatakan bahwa pasar dikatakan efisien, jika pasar merespon dengan cepat dan tepat terhadap suatu peristiwa sehingga mencapai harga keseimbangan yang baru dan telah sepenuhnya menggambarkan informasi yang tersedia.

Hanafi (2004) mendefinisikan bahwa teori efisiensi pasar adalah teori yang membahas mengenai harga atau nilai sekuritas yang mencerminkan secara penuh semua informasi yang tersedia pada informasi tersebut. Respon pasar oleh investor terhadap informasi baru merupakan hal yang perlu diperhatikan oleh perusahaan, karena harga dari saham perusahaan akan bergantung pada investor. 
Suatu peristiwa yang memiliki informasi buruk biasanya akan direspon negatif oleh pasar dan peristiwa yang memiliki informasi baik akan direspon positif oleh pasar. Suatu peristiwa yang memiliki kandungan informasi relevan bagi investor akan menimbulkan reaksi pasar yang tercermin melalui perubahan harga saham (Hartono, 2015: 624).

Reaksi pasar atas peristiwa kenaikan Fed Fund Rate dapat diukur dengan abnormal return. Apabila terdapat abnormal return di sekitar tanggal pengumuman, berarti kenaikan suku bunga merupakan pengumuman yang dapat mempengaruhi pasar. Abnormal return merupakan kelebihan return yang sesungguhnya (actual return) terhadap return normal, return normal merupakan return ekspektasian atau return yang diharapkan investor. Return sesungguhnya (actual return) adalah return yang terjadi pada waktu ke-t yang merupakan selisih harga sekarang relatif terhadap harga saham sebelumnya (Hartono, 2015:648). Jadi abnormal return merupakan selisih antara return sesungguhnya (actual return) dengan return ekspektasian (expected return).Samsul (2015) menyatakan bahwa abnormal return dapat terjadi sebelum suatu informasi diterbitkan dan dapat juga terjadi setelah informasi diterbitkan.

Reaksi pasar atas peristiwa kenaikan Fed Fund Rate juga dapat dilihat melalui pergerakan trading volume activity (TVA), dengan melihat ada tidaknya perbedaan TVA sebelum dan sesudah pengumuman kenaikan Fed Fund Rate. Menurut Suryawijaya dan Setiawan (1998) dalam Prasojo (2017), menyatakan bahwa trading volume activity (TVA) merupakan suatu instrumen yang dapat digunakanuntuk melihat reaksi pasar modal terhadap informasi melalui 
Kadek Rosita Dewi Indra Pratiwi dan I Gede Made Wirakusuma. Reaksi...

parameterpergerakan aktivitas volume perdagangan di pasar modal. Volume perdagangan saham merupakan salah satu parameter aktivitas jual beli saham di bursa, semakin meningkat jual beli saham maka aktivitas perdagangan saham dibursa juga akan semakin meningkat. Husnan (2009:56) menyatakan volume perdagangan saham diukur dengan melihat indikator aktivitas volume perdagangan saham (trading volume activity). Perhitungan trading volume activity (TVA) dilakukan dengan membandingkan jumlah saham perusahaan yang diperdagangkan dalam suatu periode tertentu dengan keseluruhan jumlah saham beredar dalam kurun waktu yang sama.

Pengujian reaksi pasar atas sebuah informasi yang dipublikasikan pernah dilakukan oleh beberapa peneliti sebelumnya, salah satunya yaitu penelitian yang dilakukan oleh Ball and Brown (1968) dalam Maharani (2004). Penelitiannya menunjukkan bahwa pasar dalam kondisi semi-kuat, sehingga ketika terjadi abnormal return negatif (return aktual kurang dari return ekspektasi), akan berbentuk bad news yang mana diperkirakan akan menyebabkan return (harga) saham menurun. Berbeda ketika terjadi abnormal return positif (return aktual lebih dari return ekspektasi), akan terbentuk good news yang menyebabkan return (harga) saham meningkat.

Selain fenomena yang telah dipaparkan, alasan lain yang melatarbelakangi penelitian ini adalah ketidakkonsistenan hasil dari penelitian-penelitian sebelumnya. Penelitian yang dilakukan Bernanke \& Kuttner (2004) mengenai reaksi pasar saham terhadap kebijakan Federal Reserve (The Fed) menyatakan bahwa pasar modal merespon adanya informasi baru yang ditunjukkan dengan 
kenaikan pada harga saham. Hasil yang berbeda dari penelitian yang dilakukan oleh Birru \& Figlewski (2010) yang menyatakan bahwa adanya pengumuman tingkat suku bunga acuan yang baru tidak direspon pasar modal, hal ini dibuktikan dengan tidak adanya perubahan return sebelum dan sesudah peristiwa pengumuman tersebut.

Penelitian oleh Linawati (2009) mengenai dampak pengumuman kenaikan BI Rate direspon oleh pasar dengan ditunjukan adanya perbedaan rata- rata trading volume activity sebelum dan setelah pengumuman, namun respon pasar tersebut tidak ditunjukkan dengan adanya abnormal return sebelum dan setelah pengumuman kenaikan BI Rate. Penelitian lain yang menyatakan bahwa kenaikan tingkat suku bunga mampu mempengaruhi pasar adalah penelitian oleh Cahyaningdyah dan Cahyasani (2017) mengenai analisis reaksi pasar modal atas pengumuman kenaikan BI Rate tanggal 12 november 2013, menunjukkan bahwa peristiwa tersebut direspon oleh pasar dengan ditunjukan adanya perbedaan ratarata trading volume activity sebelum dan setelah pengumuman kenaikan BI rate.

Penelitian oleh Ratna, dkk., (2016) dan Bramana (2017) mengenai pengaruh tingkat suku bunga, inflasi, dan nilai tukar (kurs) terhadap indeks harga saham LQ45 dan sub-sektor Perbankan di Bursa Efek Indonesia (BEI) menyimpulkan bahwa tingkat suku bunga tidak berpengaruh signfikan secara parsial terhadap indeks harga saham LQ45 dan sub-sektor Perbankan di BEI. Hal yang sama terdapat pada penelitian Asmara \& Suarjaya (2018) mengenai pengaruh varibel makro terhadap indeks harga saham gabungan yang menyatakan bahwa kenaikan suku bunga berpengaruh negatif terhadap IHSG. 
Kadek Rosita Dewi Indra Pratiwi dan I Gede Made Wirakusuma. Reaksi...

Penelitian ini menggunakan indeks LQ45 sebagai sampel, karena LQ45 merupakan salah satu indeks saham yang terdaftar di BEI yang terdiri dari 45 emiten dengan likuiditas tinggi. Selain penilaian atas likuiditas, seleksi atas emiten-emiten tersebut juga mempertimbangkan kapitalisasi pasar dan investor jangka panjang lebih sering membidik saham di LQ45 sebagai acuan investasi.

Konsep efisiensi pasar modal membahas bagaimana merespon informasiinformasi yang masuk dan bagaimana informasi tersebut selanjutnya bisa mempengaruhi pergerakan harga sekuritas menuju harga keseimbangan yang baru (Tandelilin, 2010). Indikator untuk mengukur adanya reaksi pasar dapat dilihat dari abnormal return yang diperoleh investor. Apabila terdapat abnormal return pada saat pengumuman kebijakan peningkatan tingkat suku bunga acuan oleh The Fed menandakan bahwa pasar bereaksi terhadap informasi tersebut, yang dapat mempengaruhi harga saham di Bursa Efek Indonesia (BEI).

Hipotesis ini didukung oleh penelitian Linawati (2009) dan Cahyaningdyah \& Cahyasani (2017) yang menyimpulkan bahwa tidak terdapat perbedaan abnormal return yang signifikan sebelum dan setelah peristiwa pengumuman kenaikan BI rate.

$\mathrm{H}_{1}$ : Terdapat perbedaan abnormal return sebelum dan sesudah pengumuman kenaikan tingkat suku bunga acuan oleh The Fed.

Informasi atau peristiwa tertentu dapat memicu pergerakan saham di pasar modal yang akan mempengaruhi penawaran dan permintaan saham. Adanya informasi yang beredar di pasar saham akan mengubah keyakinan investor untuk membuat keputusan. Setiap informasi yang beredar akan menimbulkan reaksi pasar. Reaksi pasar tersebut dapat dilihat dari aktivitas volume perdagangan 
saham. Volume perdagangan saham diukur dengan melihat indikator aktivitas volume perdagangan saham atau trading volume activity (TVA)(Ratna dkk., 2016). Reaksi pasar dapat dilihat dengan adanya perbedaan TVA sebelum dan sesudah suatu peristiwa. Apabila terdapat perbedaan TVA sebelum dan sesudah Pengumuman Kenaikan Tingkat Suku Bunga Acuan oleh The Fed menandakan bahwa pasar bereaksi terhadap informasi tersebut, yang dapat mempengaruhi aktivitas perdagangan saham di Bursa Efek Indonesia (BEI).

Hipotesis ini juga didukung oleh penelitian Linawati (2009) dan Cahyaningdyah \& Cahyasani (2017) mengenai dampak pengumuman kenaikan BI Rate direspon oleh pasar dengan ditunjukan adanya perbedaan rata-rata trading volume activity sebelum dan setelah pengumuman kenaikan BI Rate.

$\mathrm{H}_{2}$ : Terdapat perbedaan trading volume activity (TVA) sebelum dan sesudah pengumuman kenaikan tingkat suku bunga acuan oleh The Fed.

\section{METODE PENELITIAN}

Desain penelitian merupakan perencanaan, struktur dan strategi penelitian yang bertujuan menjawab pertanyaan yang ada. Desain dalam penelitian ini menggunakan metode penelitian kuantitatif. Metode penelitian kuantitatif dalam penelitian ini didukung dengan menggunakan pendekatan studi peristiwa (event study). Studi peristiwa (event study) merupakan studi yang mempelajari reaksi pasar terhadap suatu peristiwa yang informasinya dipublikasikan sebagai suatu pengumuman (Hartono,2015:623).Pendekatan ini akan digunakan untuk menganalisis reaksi pasar modal Indonesia atas Pengumuman Kenaikan Tingkat Suku Bunga Acuan oleh The Fed pada harga saham di Bursa Efek Indonesia (BEI). Penelitian ini dilakukan di BEI dengan mengakses situs resminya 
Kadek Rosita Dewi Indra Pratiwi dan I Gede Made Wirakusuma. Reaksi...

(www.idx.co.id). Periode pengamatan jendelaperistiwa (event window) dalam penelitian ini selama 11 hari, yaitu tanggal 15 Maret 2018 sampai dengan 29 Maret 2018.

Penelitian ini menggunakan data sekunder, yaitu data yang diperoleh dengan mengakses www.idx.co.id dan www.finance.yahoo.com. Berdasarkan hipotesis yang diajukan, variabel yang digunakan adalah variabel independen yaituPengumuman Kenaikan Tingkat Suku Bunga Acuan oleh The Fed dan variabel dependen dalam penelitian ini yaitu reaksi pasar modal Indonesia yang diproksikan dengan abnormal return dan trading volume activity. Teknik analisis yangdigunakan untuk menguji hipotesis adalah uji beda dua rata-rata (paired sample t-test). Hasil analisis kemudian diinterprestasikan untuk menjawab permasalahan.

Penelitian ini dilakukan pada perusahaan-perusahaan yang termasuk dalam indeks saham LQ45 yang terdaftar di Bursa Efek Indonesia (BEI) dengan mengakses laman www.idx.com dan finance.yahoo.com untuk mendapatkan informasi harga penutupan saham, jumlah saham beredar, dan jumlah saham yang diperdagangkan selama periode pengamatan.

Return sesungguhnya dihitung dengan rumus sebagai berikut:

$$
\mathrm{Ri}, \mathrm{t}=\frac{\mathrm{Pi}, \mathrm{t}-\mathrm{Pi}, \mathrm{t}-1}{\mathrm{Pi}, \mathrm{t}-1} .
$$

Keterangan:

$\mathrm{Ri}, \mathrm{t}=$ Actual return untuk saham i pada periode ke- $\mathrm{t}$

$\mathrm{Pi}, \mathrm{t}=$ Harga saham $\mathrm{i}$ pada periode ke-t

$\mathrm{Pi}, \mathrm{t}-1=$ Harga saham i pada periode $\mathrm{t}-1$

Return ekspetasian dapat dihitung dengan rumus sebagai berikut:

$$
E(R i, t)=R m, t
$$


Keterangan:

$$
R m, t=\frac{I H S G t-I H S G t-1}{I H S G t-1}
$$

Keterangan:

$\mathrm{Rm}, \mathrm{t}=$ Return pasar (expected return) saham i pada periode ke-t.

IHSGt = Indeks harga saham gabungan pada periode ke-t.

IHSG t-1 = Indeks harga saham gabungan pada periode ke $\mathrm{t}-1$

Abnormal return adalah selisih antara return sesungguhnya dengan return ekspetasian yang dirumuskan menggunakan market-adjusted abnormal return sebagai berikut:

$$
A R i, t=R i, t-E(R i, t)
$$

Keterangan:

ARi,t = Abnormal return saham i pada periode peristiwa ke-t

$\mathrm{Ri}, \mathrm{t}=$ Actual return saham i pada periode peristiwa ke-t

$\mathrm{E}(\mathrm{Ri}, \mathrm{t})=$ Expected return saham i pada periode peristiwa ke- $\mathrm{t}$

$$
A A R t=\frac{\sum_{i=1}^{n} A R i, t}{n} \text {. }
$$

Keterangan:

AARt $=$ Rata-rata abnormal returnperiode ke-t

ARit = Abnormal return untuk sekuritas i periode ke-t

$\mathrm{n} \quad=$ Jumlah sekuritas

Menghitung Trading Volume Activity (TVA)

$$
\text { TVAi, } \mathrm{t}=\frac{\sum \text { saham } \text { i yang diperdagangkan pada periode } t}{\sum \text { saham } \text { i yang beredar pada waktu } t}
$$

Keterangan:

TVAi, $\mathrm{t}=$ Volume perdagangan saham i pada periode ke-t

Rata-rata trading volume activity dihitung dengan rumus:

$$
A T V A=\frac{\sum_{i=1}^{n} T V A i, t}{n}
$$

Keterangan: 
Kadek Rosita Dewi Indra Pratiwi dan I Gede Made Wirakusuma. Reaksi...

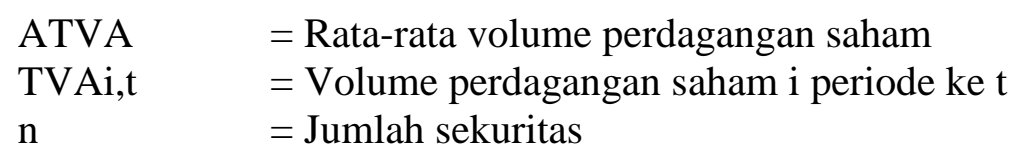

Dalam penelitian ini yang menjadi populasi adalah perusahaan-perusahaan yang terdaftar di Bursa Efek Indoensia (BEI) tahun 2018.Sampel dalam penelitian ini adalah perusahaan-perusahaan yang termasuk ke dalam indeks saham LQ45 di Bursa Efek Indonesia (BEI) periode Februari 2018 sampai dengan Juli 2018.

Metode penentuan sampel yang digunakan dalam penelitian ini adalah metode non-probability sampling. Metode pengumpulan data yang digunakan dalam penelitian ini adalah metode observasi non partisipan, yaitu metode pengumpulan data dengan melakukan pengamatan namun peneliti tidak terlibat dan hanya sebagai pengamat independent.

Uji paired sample t-test merupakan uji parametrik yang digunakan untuk menguji hipotesis sama atau tidak berbeda $\left(\mathrm{H}_{0}\right)$. Model uji beda ini digunakan untuk menganalisis model penelitian pre-post atau sebelum dan sesudah. Uji beda digunakan untuk mengevaluasi perlakuan (treatment) tertentu pada satu sampel yang sama pada dua periode pengamatan yang berbeda (Pramana, 2012).

\section{HASIL DAN PEMBAHASAN}

Statistik deskriptif berhubungan dengan pengumpulan dan peringkat data yang menggambarkan karakteristik sampel yang digunakan dalam penelitian ini. Analisis ini berguna untuk menjelaskan karateristik sampel terutama mencakup nilai rata-rata (mean), nilai ektrim yaitu nilai minimum dan nilai maksimum, serta standar deviasi dari masing-masing variabel. Hasil dari statistik deskriptif tersebut dapat dilihat pada Tabel 1 berikut ini: 
Tabel 1.

Hasil Statistik Deskriptif

Pengumuman Kenaikan Tingkat Suku Bunga Acuan oleh The Fed

\begin{tabular}{lccccc}
\hline & N & Minimum & Maximum & Mean & Std. Deviation \\
\hline AR_Sebelum & 45 & -0.0155 & 0.0135 & -0.0001 & 0.0069 \\
AR_Sesudah & 45 & -0.0243 & 0.0955 & 0.0007 & 0.0163 \\
TVA_Sebelum & 45 & 0.0002 & 0.0079 & 0.0017 & 0.0016 \\
TVA_Sesudah & 45 & 0.0002 & 0.0051 & 0.0014 & 0.0012 \\
\hline \multicolumn{2}{l}{ Sumber: Data diolah, 2018} & & & &
\end{tabular}

Berdasarkan Tabel 1 dapat dilihat bahwa secara statistik abnormal return (AR) perusahaan LQ45 pada lima hari sebelum pengumuman kenaikan tingkat suku bunga acuan oleh The Fed (Fed Fund Rate) memiliki rata-rata sebesar 0,0001dengan rata-rata penyimpangan abnormal return sebesar 0,0069. Hal ini menunjukkan terdapat rata-rata abnormal return negatif yang berarti bahwa return aktual yang terjadi lebih rendah daripada return yang diharapkan. Pada abnormal return (AR) perusahaan LQ45 lima hari sesudah pengumuman kenaikan Fed Fund Rate memiliki rata-rata sebesar 0,0007 dengan rata-rata penyimpangan abnormal return sebesar 0,0163. Hal ini menunjukkan terdapat rata-rata abnormal return positif yang berarti bahwa return aktual yang terjadi lebih tinggi daripada return yang diharapkan.

Nilai minimum rata-rata abnormal return atau rata-rata abnormal return terendah sebelum pengumuman kenaikan Fed Fund Rate pada perusahaan LQ45 terjadi pada Telekomunikasi Indonesia (Persero) Tbk. dengan nilai sebesar 0,0155 , sedangkan nilai maksimum rata-rata abnormal return atau rata-rata abnormal return tertinggi terjadi pada Chandra Asri Petrochemical Tbk. dengan nilai sebesar 0,0135. Pada periode sesudah pengumuman kenaikan Fed Fund Rate, nilai minimum rata-rata abnormal return terjadi pada Trada Alam Minera 
Kadek Rosita Dewi Indra Pratiwi dan I Gede Made Wirakusuma. Reaksi...

Tbk dengan nilai sebesar -0,0243, sedangkan nilai maksimum rata-rata abnormal return terjadi pada BPD Jawa Barat dan Banten Tbk. dengan nilai sebesar 0,0955.

Pada trading volume activity (TVA) perusahaan LQ45 lima hari sebelum pengumuman kenaikan tingkat suku bunga acuan oleh The Fed(Fed Fund Rate) memiliki rata-rata sebesar 0,0017dengan rata-rata penyimpangan TVA sebesar 0,0016. Pada lima hari sesudah pengumuman kenaikan Fed Fund Rate terdapat rata-rata TVA sebesar 0,0014 dengan rata-rata penyimpangan sebesar 0,0012. Hal ini menunjukkan terdapat rata-rata TVApositif baik sebelum dan sesudah pengumuman, namun jika dibandingkan baik rata-rata TVA sebelum dan sesudah pengumuman mengalami penurunan. Ini berarti terjadi penurunan secara rata-rata pada volume perdagangan saham.

Nilai minimum rata-rata TVA atau rata-rataTVA terendah baik sebelum ataupun sesudah pengumuman kenaikan Fed Fund Rate pada perusahaan LQ45 terjadi pada H. M. Sampoerna Tbk. dengan nilai sebesar 0,0002, sedangkan nilai maksimum rata-rata TVA atau rata-rata TVA tertinggi sebelum pengumumankenaikan Fed Fund Rate terjadi pada Bumi Resources Tbk. dengan nilai sebesar 0,0079 dan nilai maksimum rata-rata TVA atau rata-rata TVA tertinggi sesudah pengumuman kenaikan Fed Fund Rate terjadi pada Hanson International Tbk. dengan nilai sebesar 0,0051 . 


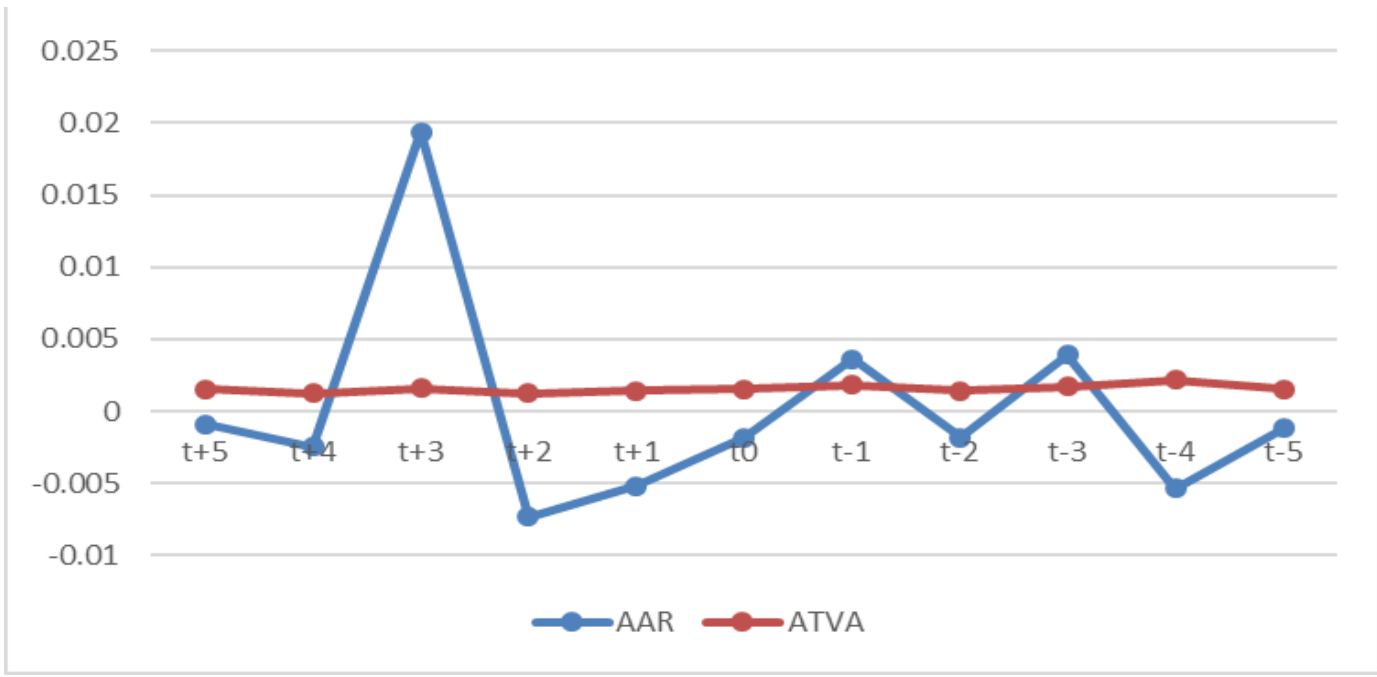

Sumber:Data diolah, 2018

Gambar 1. Grafik Rata-Rata Abnormal Return dan Trading Volume Activity

Gambar 1 menunjukkan fluktuasi rata-rata abnormal return dan trading volume activity pada periode pengamatan peristiwa pengumuman kenaikan tingkat suku bunga acuan oleh The Fed. Nilai abnormal return tertinggi terjadi pada saat $\mathrm{t}+3$ dan terendah pada saat $\mathrm{t}+2$. Nilai trading volume activity tertinggi terjadi pada saat $\mathrm{t}-4$ dan terendah pada saat $\mathrm{t}+4$.

Perbedaan abnormal return (AR) sebelum dan sesudah pengumuman kenaikan tingkat suku bunga acuan oleh The Fed. Pengujian hipotesis ini menggunakan paired samples t-test yang diolah dengan software SPSS 13.0 for windows. Hasil uji hipotesis perbedaan abnormal return sebelum dan sesudah peristiwa pengumuman kenaikan tingkat suku bunga acuan oleh The Fed dapat diketahui pada Tabel 2 berikut ini: 
Tabel 2.

Hasil Uji Hipotesis Rata-rataAbnormal Return

\begin{tabular}{|c|c|c|c|}
\hline & & & Pair 1 \\
\hline & & & $\begin{array}{c}\text { AAR Sebelum -AAR } \\
\text { Sesudah }\end{array}$ \\
\hline Paired Differences & Mean & & -0.0009 \\
\hline & Std. Deviation & & 0.0180 \\
\hline & Std. Error Mean & & 0.0027 \\
\hline & $95 \%$ Confidence Interval & Lower & -0.0063 \\
\hline & of the Difference & Upper & 0.0046 \\
\hline $\mathrm{T}$ & & & -0.3190 \\
\hline Df & & & 44 \\
\hline sig. (2-tailed) & & & 0.7510 \\
\hline
\end{tabular}

Sumber:Data diolah, 2018

Tabel 2. menunjukkan nilai sig. (2-tailed) 0,7510. Nilai ini menyatakan bahwa tidak terdapat perbedaan rata-rata abnormal return sebelum dan sesudah pengumuman kenaikan tingkat suku bunga acuan oleh The Fed karena sig. (2tailed) 0,7510 lebih besar dari 0,05. Nilai sig. (2-tailed) tersebut menyatakan bahwa $\mathrm{H}_{1}$ ditolak dan $\mathrm{H}_{0}$ diterima.

Perbedaan Trading volume activity Sebelum dan Sesudah pengumuman Kenaikan Tingkat Suku Bunga Acuan oleh The Fed. Hasil uji hipotesis perbedaan trading volume activity sebelum dan sesudah pengumuman kenaikan tingkat suku bunga acuan oleh The Fed dapat diketahui pada Tabel 3 berikut ini:

Tabel 3.

Hasil Uji Hipotesis Rata-rata Trading Volume Activity

\begin{tabular}{|c|c|c|c|}
\hline & & & Pair 1 \\
\hline & & & $\begin{array}{c}\text { ATVA Sebelum - } \\
\text { ATVA Sesudah }\end{array}$ \\
\hline \multirow[t]{5}{*}{ Paired Differences } & Mean & & 0.0004 \\
\hline & Std. Deviation & & 0.0009 \\
\hline & Std. Error Mean & & 0.0001 \\
\hline & 95\% Confidence Interval & Lower & 0.0001 \\
\hline & of the Difference & Upper & 0.0006 \\
\hline $\mathrm{T}$ & & & 2.6530 \\
\hline Df & & & 44 \\
\hline sig. (2-tailed) & & & 0.0110 \\
\hline
\end{tabular}

Sumber: Data diolah, 2018 
Tabel 3 menunjukkan nilai sig. (2-tailed) 0,0110. Nilai ini menyatakan bahwa terdapat perbedaan trading volume activity sebelum dan sesudah pengumuman kenaikan tingkat suku bunga acuan oleh The Fed karena sig. (2tailed) 0,0110 lebih kecil dari 0,05. Nilai sig. (2-tailed) tersebut menyatakan bahwa $\mathrm{H}_{2}$ diterima dan $\mathrm{H}_{0}$ ditolak.

Seluruh informasi yang relevan di dalam pasar modal efesien yang berkaitan dengan perusahaan yang go public akan tercermin dari harga-harga sahamnya. Munculnya informasi yang baru seperti halnya pengumuman kenaikan Fed Fund Rate (FFR) akan dengan segera dipersepsikan oleh investor, namun persepsi dari para investor atas informasi baru tidak selalu sama sehingga menimbulkan reaksi yang berbeda diantara para investor tersebut. Gabungan dari seluruh reaksi investor atas informasi baru yang menyangkut suatu saham akan membentuk suatu reaksi pasar atas informasi baru tersebut.

Penelitian ini bertujuan untuk mengetahui reaksi pasar atas pengumuman kenaikan tingkat suku bunga acuan oleh The Fed. Reaksi pasar yang terjadi akan tercermin dari perubahan harga saham yang diukur dengan menggunakan abnormalreturn, yang dilihat dari ada tidaknya perbedaan rata-rata abnormal return lima hari sebelum dan lima sesudah pengumuman tersebut. Berdasarkan hasil pengujian hipotesis dengan menggunakan paired samples t-test yang ditunjukkan pada Tabel 4.5, dapat diketahui bahwa tingkat signifikansi (Sig. 2tailed) sebesar 0,7510 yang menunjukkan angka lebih besar dari taraf nyata dalam penelitian ini yaitu $\alpha=0,05$ dan thitung sebesar $-0,3190$ lebih kecil dari tabel sebesar 2,0167. Hal ini menyatakan bahwa $\mathrm{H}_{0}$ diterima dan $\mathrm{H}_{1}$ ditolak, yang berarti tidak 
Kadek Rosita Dewi Indra Pratiwi dan I Gede Made Wirakusuma. Reaksi...

terdapat perbedaan rata-rata abnormal return sebelum dan sesudah pengumuman kenaikan tingkat suku bunga acuan oleh The Fed. Hasil ini menunjukkan bahwa pasar tidak bereaksi atas peristiwa pengumuman kenaikan tingkat suku bunga acuan oleh The Fed.

Pengumuman kenaikan Fed Fund Rate (FFR) dikatakan sebagai suatu pengumuman yang memberikan signal bagi pasar baik positif maupun negatif maka pasar akan bereaksi dengan adanya abnormal return. Namun, dari pengujian terhadap hipotesis satu $\left(\mathrm{H}_{1}\right)$, tidak ditemukan adanya perbedaan yang signifikan antara rata-rata abnormal return sebelum dan sesudah peristiwa pengumuman kenaikan Fed Fund Rate, sehingga hipotesis yang menyatakan terdapat reaksi pasar yang ditunjukkan dengan perbedaan rata-rata abnormal return pada periode sebelum dan sesudah pengumuman kenaikan tingkat suku bunga acuan oleh The Fed pada Indeks LQ45 tidak terbukti. Hal ini menunjukkan bahwa kondisi pasar modal Indonesia berjalan dengan normal walaupun ada kebijakan baru yang dikeluarkan oleh Bank Sentral AS (The Fed). Investor dapat mempertimbangkan informasi kenaikan Fed Fund Rate dan memperhitungkan risiko yang akan terjadi pada perusahaan setelah adanya kebijakan tersebut sehingga disamping mendapatkan return yang tinggi, dana yang telah mereka tanamkan di pasar modal tidak akan terkena dampak negatif dari adanya kebijakan yang dikeluarkan oleh The Fed.

Hasil penelitian ini sejalan dengan penelitianolehLinawati (2009), dan Cahyaningdyah \& Cahyasani (2017) yang menyimpulkan bahwa kenaikan BI Rate direspon oleh pasar dengan ditunjukan adanya perbedaan rata- rata trading 
volume activity sebelum dan setelah pengumuman, namun respon pasar tersebut tidak ditunjukkan dengan adanya abnormal return sebelum dan setelah pengumuman kenaikan BI Rate. Penelitian ini juga sejalan dengan penelitian oleh Birru \& Figlewski (2010) menyatakan bahwa pengumuman tingkat suku bunga acuan yang baru tidak direspon pasar modal dibuktikan dengan tidak adanya perubahan return sebelum dan sesudah peristiwa pengumuman tersebut.

Penelitian ini bertujuan untuk mengetahui pengaruh pengumuman kebijakan kenaikan tingkat suku bunga acuan oleh The Fed terhadap reaksi pasar yang diproksikan dengan trading volume activity (TVA). Reaksi pasar terhadap peristiwa ini dilihat dari ada tidaknya perbedaan TVA baik sebelum maupun sesudah peristiwa pengumuman kenaikan tingkat suku bunga acuan oleh The Fed.

Dari hasil penelitian hipotesis dengan menggunakan pengujian paired sample $t$-test yang ditunjukkan pada Tabel 4.6, diketahui bahwa tingkat signifikansi (Sig. 2-tailed) sebesar 0,0110 yang menunjukkan angka lebih kecil dari taraf nyata dalam penelitian ini yaitu $\alpha=0,05$ dan $t_{\text {hitung }}$ sebesar 2,6530 lebih besar dari $t_{\text {tabel }}$ sebesar 2,0167. Hal ini menyatakan bahwa $\mathrm{H}_{0}$ ditolak dan $\mathrm{H}_{2}$ diterima, yang berarti terdapat perbedaan rata-rata TVAsebelum dan sesudah Pengumuman Kenaikan Tingkat Suku Bunga Acuan oleh The Fed. Hasil ini menunjukkan bahwa pasar bereaksi atas peristiwa pengumuman kenaikan tingkat suku bunga acuan oleh The Fed.

Hasil uji statistik deskriptif diketahui rata-rata aktivitas volume perdagangan saham perusahaan yang termasuk dalam indeks LQ45 mengalami penuruanan setelah terjadinya peristiwa pengumuman kenaikan tingkat suku 
bunga acuan oleh The Fed, yaitu dari lima hari sebelum peristiwa memiliki ratarata sebesar 0,0017 menjadi 0,0014 lima hari sesudah terjadinya peristiwa tersebut. Hal ini menunjukkan terdapat rata-rata trading volume activity negatif yang berarti bahwa terjadi penurunan secara rata-rata pada volume perdagangan saham.

Berdasarkan penelitian-penelitian sebelumnya, hubungan antara tingkat suku bunga dengan kegiatan investasi adalah negatif. Apabila tingkat suku bunga mengalami penurunan maka investasi akan mengalami peningkatan dan sebaliknya apabila tingkat suku bunga mengalami kenaikan maka investasi mengalami penurunan. Hal ini sejalan dengan hasil yang didapatkan yaitu terdapat rata-rata trading volume activity negatif yang berarti bahwa terjadi penurunan secara rata-rata terhadap volume perdagangan saham. Hasil penelitian ini membuktikan bahwa adanya informasi baru mengenai kenaikan Fed Fund Rate memberikan dampak negatif terhadap aktivitas volume perdagangan saham di pasar modal Indonesia. Pada saat peristiwa kenaikan Fed Fund Rate diumumkan, investor memilih untuk menjual sahamnya karena diprediksi akan memberikan dampak negatif terhadap harga saham di BEI dan memilih untuk mengalihkan investasinya ke instrumen perbankan seperti deposito. Ketika suku bunga The Fed naik, investor asing di Pasar Modal Indonesia memutuskan untuk berinvestasi di Amerika Serikat, karena dengan naiknya suku bunga acuan The Fed investor akan mendapatkan keuntungan yang lebih banyak bila dibandingkan dengan bermain saham di Indonesia. Hasil penelitian ini dibuktikan dengan adanya penurunan rata-rata aktivitas perdagangan saham atau terdapat rata-rata trading volume 
activity negatif sesudah terjadinya peristiwa pengumuman kenaikan Fed Fund Rate.

Hasil penelitian ini konsisten dengan penelitian sebelumnya yang dilakukan oleh Cahyaningdyah dan Cahyasani (2017) yang menyatakan bahwa terdapat perbedaan rata-rata trading volume activity sebelum dan sesudah peristiwa pengumuman kenaikan BI Rate, dan penelitin oleh Ratna dkk., (2016), Bramana (2017) dan Asmara \& Suarjaya (2018)yang menyatakan bahwa kenaikan tingkat suku bunga berpengaruh negatif terhadap indeks harga saham.

Penelitian ini menghasilkan simpulan mengenai bagaimana reaksi pasar modal Indonesia atas pengumuman kenaikan tingkat suku bunga acuan oleh The Fed. Hasil uji dalam penelitian ini ditemukan bahwa reaksi pasar ditunjukkan dengan adanya perbedaan rata-rata trading volume activity sebelum dan sesudah peristiwa pengumuman kenaikan tingkat suku bunga acuan oleh The Fed, namun tidak ditunjukkan dengan adanya abnormal return.

Pada event study theory melakukan pengujian kandungan informasi yang dimaksudkan untuk melihat reaksi pasar atas suatu pengumuman (Hartono, 2015:623). Reaksi pasar diukur menggunakan abnormal return dan trading volume activity (TVA). Pasar dikatakan bereaksi atas suatu pengumuman apabila dapat memberikan abnormal return pada pasardan memengaruhi volume perdagangan saham. Bila diukur menggunakan abnormal return, Pengumuman kenaikan Fed Fund Rate tidak memiliki kandungann informasi yang dapat mempengaruhi preferensi investor dalam pengambilan keputusan investasi. Namun bila diukur menggunakan TVA, Pengumuman kenaikan Fed Fund Rate 
Kadek Rosita Dewi Indra Pratiwi dan I Gede Made Wirakusuma. Reaksi...

memiliki kandungan informasi negatif, yang dapat mempengaruhi investor untuk melakukan aktivitas penjualan saham sehingga menyebabkan terjadinya penurunan terhadap volume perdagangan saham.

Penelitian ini mendukung penelitian oleh Linawati (2009) dan Cahyaningdyah \& Cahyasani (2017) bahwa tidak terdapat perbedaan abnormal return yang signifikan sebelum dan sesudah pengumuman kenaikan BI rate, namun reaksi pasar ditunjukkan dengan adanya perbedaan TVA sebelum dan sesudah pengumuman BI rate. Penelitian ini juga mendukung penelitian oleh Birru \& Figlewski (2010) yang menyimpulkan bahwa pasar modal tidak bereaksi atas pengumuman tingkat suku bunga acuan yang baru dibuktikan dengan tidak adanya perubahan return sebelum dan sesudah peristiwa pengumuman tersebut.

Penelitian ini memberikan implikasi bagi para pelaku pasar sebagai pengetahuan dan pertimbangan dalam pengambilan keputusan berinvestasi. Dari penelitian ini dapat diketahui bahwa faktor ekonomi makro atau faktor eksternal dapat memengaruhi keputusan investor dalam berinvestasi salah satunya yaitu tingkat suku bunga. Hasil dari penelitian ini menyatakan bahwa pasar modal Indonesia bereaksi atas peristiwa pengumuman kenaikan tingkat suku bunga acuan oleh Bank sentral AS (The Fed), yang ditunjukkan dengan adanya perbedaan rata-rata trading volume activity sebelum dan sesudah peristiwa tersebut, namun tidak ditunjukkan dengan adanya perbedaan abnormal return. Hasil penelitian ini memberikan bukti bahwa peristiwa tersebut menimbulkan perubahan terhadap aktivitas perdagangan saham yang dilihat dari perbedaan ratarata TVA yang negatif. 
Penelitian ini diharapkan mampu membantu investor sebagai pertimbangan dalam pengambilan keputusan berinvestasi di masa mendatang. Investor dapat mempertimbangkan informasi kenaikan tingkat suku bunga acuan oleh bank sentral AS (Fed Fund Rate) dan bagaimana pengaruhnya terhadap pasar modal di Indonesia. Investor juga harus memperhitungkan risiko yang akan terjadi pada perusahaan setelah adanya kebijakan tersebut sehingga disamping mendapatkan return yang tinggi, dana yang telah investor tanamkan di pasar modal tidak akan terkena dampak negatif dari adanya kebijakan kenaikan $\mathrm{Fed}$ Fund Rate.

\section{SIMPULAN}

Pasar tidak bereaksi atas pengumuman kenaikan tingkat suku bunga acuan oleh The Fed yang ditunjukkan dengan tidak adanya perbedaan rata-rata abnormal return baik sebelum dan sesudah peristiwa tersebut. Dengan demikian dapat dikatakan bahwa pengumuman kenaikan tingkat suku bunga acuan oleh The Fed (Fed Fund Rate)tidak menyebabkan pergerakan atau memberikan pengaruh terhadap abnormal return di pasar modal Indonesia.

Pasar bereaksi atas pengumuman kenaikan tingkat suku bunga acuan oleh The Fed yang ditunjukkan dengan adanya perbedaan rata-rata trading volume activity sebelum dan sesudah peristiwa tersebut. Dengan demikian dapat dikatakan bahwa Pengumuman Kenaikan Tingkat Suku Bunga Acuan oleh The Fed (Fed Fund Rate)dapat memengaruhi keputusan investor dalam bertransaksi di pasar modal, sehingga menimbulkan perbedaan rata-rata TVA. 
Kadek Rosita Dewi Indra Pratiwi dan I Gede Made Wirakusuma. Reaksi...

Penulis menyadari banyak kekurangan dari penelitian ini, sehingga diharapkan bagi peneliti selanjutnya untuk menyempurnakannya. Penelitian ini hanya menggunakan abnormal return dan trading volume activity untuk mengukur reaksi pasar terhadap peristiwa pengumuman kenaikan Fed Fund Rate. Penelitian ini juga hanya menggunakan peristiwa dari kebijakan yang dikeluarkan oleh Bank Sentral AS (The Fed) yang memberikan pengaruh besar terhadap pasar modal dunia. Peneliti selanjutnya diharapkan dapat menggunakan peristiwa dari negara lain seperti negara China yang merupakan salah satu raksasa ekonomi dunia selain AS.

Bagi investor diharapkan mempertimbangkan faktor-faktor yang dapat mempengaruhi pengambilan keputusan dalam berinvestasi, baik faktor internal maupun faktor eksternal. Salah satu faktor makro ekonomi (eksternal) yaitu tingkat suku bunga. Tingkat suku bunga dapat dijadikan pertimbangan para inevestor dalam melakukan investasi.

\section{REFERENSI}

Alwi, Z Iskandar. (2003). Pasar Modal: Teori dan Aplikasi. Edisi Pertama. Jakarta: Nasindo Internusa.

Asmara, W. P., \& Suarjaya, A. G. (2018). Pengaruh Variabel Makro Ekonomi Terhadap Indeks harga Saham Gabungan. E-Jurnal Manajemen Unud, 7(3), 1397-1425.

Bernanke, B. S., \& Kuttner, K. N. (2004). What Explains the Stock Market's Reaction to Federal Reserve Policy?, 60(3), 1221-1257.

Birru, J., \& Figlewski, S. (2010). The Impact of the Federal Reserve' s Interest Rate Target Announcement on Stock Prices: A Closer Look at How the Market Impounds New Information. Finance Journal,New York University, 1-44.

Boediono. (2014). Ekonomi Makro.Yogyakarta: BPFE. 
Bramana, S. M. (2017). Analisis Pengaruh Inflasi , Suku Bunga, dan Nilai Tukar (Kurs) terhadap Indeks Harga Saham LQ45 yang Listing Di Bursa Efek Indonesia (BEI). KOLEGIAL, 3(2), 2088-5644.

Bursa Efek Indonesia. (2018). Saham Diperdagangkan Perusahaan Tercatat yang masuk dalam penghitungan Indek Saham LQ45 Periode Februari sampai Juli 2018. https://idx.co.id/. Diakses 11 Agustus 2018.

Cahyaningdyah, Dwi; Cahyasani, N. A. (2017). Analisis Reaksi Pasar Modal atas pengumuman Kenaikan BI Rate Tanggal 12 November 2013. Jurnal Maksipreneur, VI(2), 56-64.

Dewi, A. T., \& Rahyuda, H. (2014). Studi Empiris Abnormal Return Sebelum dan Sesudah Pengumuman Right Issue Pada Perusahaan Go Public Di Bursa Efek Indonesia. E-Jurnal Akuntansi Universitas Udayana, 3(11), 34553472. Retrieved

from https://ojs.unud.ac.id/index.php/Manajemen/article/view/9881

Dewi, I.G.A. Ayu Pradnyani Harum. (2017). Reaksi Pasar Modal Indonesia atas Kebijakan Tax Amnesty. Tesis. Fakultas Ekonomi dan Bisnis, Universitas Udayana.

Hartono, Jogiyanto. (2015). Teori Portofolio dan Analisis Investasi. Edisi Kedelapan. Yogyakarta: BPPE.

Husnan, Suad. (2009). Dasar-Dasar Teori Portofolio dan Analisis Sekuritas. Edisi Keempat. AMP YPKN. Yogyakarta.

Linawati, D. (2009). Dampak Pengumuman Kenaikan BI Rate Tanggal 07 Oktober 2008 Terhadap Abnormal Return dan Trading Volume Activity. Diponegoro Journal of Management, 1-87.

Maharani, A. A. I. (2014). Respon Pasar Atas Informasi Laba (Replikasi Ball dan Brown 1968). E-Jurnal Akuntansi Universitas Udayana, 8(1), 83-93.

Parmadi, N. K. A. R., Adiputra, I. M. P., \& Dharmawan, N. A. S. (2014). Analisis Reaksi Investor Terhadap Kenaikan Harga Bahan Bakan Minyak di Bursa Efek Indonesia. E-Journal Akuntansi Universitas Pendidikan Ganesha, 2(1).

Pemerintah Indonesia. (1995). Undang-undang Nomor 8 Tahun 1995 tentang Pasar Modal. Sekretariat Negara, Jakarta.

Prasojo, H. S. U. (2014). Reaksi Pasar Saham terhadap Pengumuman Krisis Finansial Global. Fakultas Ekonomi Dan Bisnis, Universitas Brawijaya. 
Kadek Rosita Dewi Indra Pratiwi dan I Gede Made Wirakusuma. Reaksi...

https://doi.org/10.1017/CBO9781107415324.004

Ratna, M., Ginting, M., \& Sulasmiyanti, S. (2016). Pengaruh Tingkat Subu Bunga, Nilai Tukar dan Inflasi terhadap Harga Saham. E-Journal Fakultas Ilmu Administrasi, Univeristas Brawijaya, 35(2), 77-85.

Samsul, Muhammad. (2015). Pasar Modal dan Manajemen Portofolio. Edisi 2. Jakarta: Erlangga.

Tandelilin, Eduardus. (2010). Portofolio dan Investasi Teori dan Aplikasi. Edisi Pertama. Yogyakarta: Kanisius IKAPI. 